\title{
BurEAUCRATIC CORRUPTION AND PROFIT TAX EVASION
}

\author{
LASZLO GOERKE
}

\author{
CESIFO WORKING PAPER No. 1666 \\ CATEgORY 1: Public FinANCE \\ FEBRUARY 2006
}

An electronic version of the paper may be downloaded
- from the SSRN website: $\quad$ www.SSRN.com
- from the CESifo website: $\quad$ www.CESifo-group.de 


\title{
BUREAUCRATIC CORRUPTION AND PROFIT TAX EVASION
}

\begin{abstract}
Firms may evade taxes on profits and can also avoid fulfilling legal restrictions on production activities by bribing bureaucrats. It is shown that the existence of tax evasion does not affect corruption activities at the firm level, while the budgetary repercussions of tax evasion induce less corruption. Policy measures which alter the gains or losses from corruption have a nonsystematic impact on tax evasion behaviour.
\end{abstract}

JEL Code: D73, H25, H26.

Keywords: corruption, firms, tax evasion.

\author{
Laszlo Goerke \\ Johannes Gutenberg University Mainz \\ Department of Economics (FB 03) \\ 55099 Mainz \\ Germany \\ Laszlo.Goerke@uni-mainz.de
}

I am grateful for helpful comments by Tim Friehe and two anonymous referees and, moreover, to CESifo for its hospitality when revising the paper. Obviously, I bear the sole responsibility for any remaining deficiency. 


\section{Motivation and Survey of the Literature}

Economies characterised by a great extent of corruption are argued to be plagued by substantial tax evasion activities as well (Tanzi and Davoodi 2001). Since corruption and tax evasion are, by nature, difficult to measure, the empirical evidence for an according relationship is scarce. However, with the exception of fiscal corruption, there are also relatively few theoretical investigations. Chu (1990) and Bowles (1999), for example, find that corruption among tax enforcement agents increases income tax evasion since the effective penalty declines, providing a theoretical argument for a positive link between tax evasion and corruption. Sanyal (2000, 2002), Hindriks et al. (1999), and Besley and McLaren (1993) investigate the impact of alternative reward schemes on the behaviour of corrupt tax officials and the level of corruption. In addition, Chander and Wilde (1992) and Sanyal et al. (2000) show that tax revenues may decline with the income tax rate in the presence of corrupt tax officials. Since tax evasion entails corruption, this 'Laffer-curve' effect is also compatible with a positive relation between the two illegal activities.

While fiscal corruption establishes a direct impact of corruption on tax evasion, corruptive behaviour can also have an indirect effect. First, in a society in which individual behaviour is influenced by social norms, these norms may apply equally to tax evasion and corruption. Second, if tax evasion is only feasible for income generated unofficially and, in addition, activities in the shadow economy require bribing government employees, corruption and tax evasion are positively correlated. Third, the incentives to evade taxes may be altered if corruption is feasible, and vice versa. This list of linkages between tax evasion and corruption is certainly not exhaustive. However, it suggests that corruption among tax officials is not the only feasible connection between the two illegal activities. Ascertaining the existence of such a link and also its details can be important for a number of reasons: first, since evasion reduces tax revenues and, thereby, the supply of public goods, a positive association between corruption and tax evasion will further question the "efficient grease hypothesis" (Kaufmann and Wei 1999) according to which corruption can enhance the efficiency of an economy strangled by excessive government regulation. Second, a positive relationship between evasion and corruption can provide an additional explanation for the observation that countries with higher levels of corruption collect fewer taxes per unit of GDP than those with 
less corruption. ${ }^{1}$ Finally, any correlation between evasion and corruption will alter the optimal amount of resources spent on combating these types of illegal behaviour.

The present paper investigates one particular mechanism by which corporate tax evasion and corruption can be related. It looks at the respective linkage in a setting in which firms can evade a tax on profits and purchase production licences illegally. By focussing on firms, issues of risk-aversion can be averted. Hence, the analysis does not have to rely on viewing tax evasion as a gamble which requires implausibly high measures of risk-aversion to explain observed (individual) tax evasion behaviour (Alm 1999). The gains from corruption consist in a lower expenditure for legally acquiring production licences. Tax evasion and corruption are, therefore, related insofar as that substituting corruption expenses for expenditure caused by legal actions can alter the costs of evading taxes.

Section 2 sets out the basic model. The analysis shows that tax evasion does not affect input and corruption choices. Moreover, input decisions do not alter tax evasion either. Therefore, the well-established two-directional independence of production and tax evasion choices also holds in the presence of corruption activities. However, changes in exogenous variables which affect corruption also have an impact on tax evasion. Section 3 accordingly analyses for the basic model whether the existence of tax evasion indirectly affects corruption. Section 4 inquires whether and how policies that alter corruption affect tax evasion behaviour and whether a positive correlation - as suggested by the links discussed above - can be established. In Section 5, two extensions of the basic model are looked at to investigate the robustness of the findings. Section 6 summarises and draws some tentative conclusions.

\section{Model}

\subsection{Foundations}

The production sector of the economy can be represented by a fixed number of identical firms. Each firm uses one factor k, which is subsequently labelled 'capital' for simplicity, in order to produce the quantity $f$ of a homogeneous good, where $f(k)$ depicts the strictly concave production function, $\mathrm{f}^{\prime}>0, \mathrm{f}^{\prime \prime}<0, \mathrm{f}^{\prime}(0) \rightarrow \infty$. Output sells at a unit price. As a complement to capital, production requires a number $\mathrm{p}$ of what we will call permits or production licences. Permits can be thought of as certificates provided by government agencies which state that health, safety, sanitary and fire regulations, environmental

\footnotetext{
${ }^{1}$ See Johnson et al. (1999) and Tanzi and Davoodi $(1998,2001)$ for according evidence. Friedman et al. (2000) do not find such a link.
} 
requirements, workplace rules or certification measures have been fulfilled. In a wider sense, permits may also represent the bureaucratic requirements which firms have to fulfil by reporting information to statistical offices, the tax authority or social security institutions, local government agencies or a government agency attempting to prevent discrimination of minorities. The decisive feature of these permits is that they are a prerequisite for production, raise the costs of firms and can potentially be obtained illegally by bribing the government official in charge of granting them. The existence of regulatory requirements as captured by the concept of 'permits' generates the possibility for bureaucratic corruption. ${ }^{2}$ The number of permits p required represents the extent of regulation in the economy and increases with the amount of capital, $\mathrm{p}=\mathrm{p}(\mathrm{k}), \mathrm{p}^{\prime}(\mathrm{k})>0$. Moreover, $\mathrm{p}(0)=\mathrm{p}^{\prime}(0)=0$ and $\mathrm{p}^{\prime \prime}(\mathrm{k}) \geq 0$ are presumed. The convex relationship between $\mathrm{p}$ and $\mathrm{k}$ rests on the assumption that the regulatory requirements for larger firms are more extensive than according rules for smaller companies. This can be an adequate assumption as small and medium-sized firms are often exempted, for example, from some environmental, sanitary or safety requirements and labour standards. ${ }^{3}$

Production can only take place if a firm owns the required number of permits, irrespective of whether they have been acquired in accordance with the law or have been bought illegally. This assumption reflects the insight that it is easily observable whether a firm possesses the number of required certificates or permits and that it will immediately be closed down if permits are missing. However, it is much more difficult to ascertain whether all permits have been obtained legally. Obtaining permits is costly for the firm either because it uses resources to warrant the safety, health, workplace and environmental standards which are required to legally obtain certificates, or because attaining the permits illegally implies purchasing them from corrupt bureaucrats. If the firm obtains all the required permits legally, this will cost $\mathrm{C}(\mathrm{p}(\mathrm{k}))$. The cost function $\mathrm{C}$ is strictly convex, implying $\mathrm{C}^{\prime}(\mathrm{p}(\mathrm{k})), \mathrm{C}^{\prime \prime}(\mathrm{p}(\mathrm{k}))>0$ for $\mathrm{p}(\mathrm{k})>0$, and warrants $\mathrm{C}(0)=\mathrm{C}^{\prime}(0)=0$. The costs of fulfilling the regulatory requirement in the presence of corruption amount to $\mathrm{C}(\mathrm{p}(\mathrm{k})-\mathrm{x})+\mathrm{bx}$, where $\mathrm{x}$ is the number of permits purchased illegally. The price $\mathrm{b}$ of procuring a permit illegally can include bribe payments to corrupt government employees, the penalty if caught, and the costs of hiding corruption activities. For simplicity, expected costs b per permit acquired illegally are referred to as

\footnotetext{
${ }^{2}$ This notion of corruption is akin to Shleifer and Vishny's (1993, p. 599) perception: "We define government corruption as the sale by government officials of government property for personal gain. For example, government officials often collect bribes for providing permits and licences, ... . Licences, permits, passports and visas are needed to comply with laws and regulations that restrict private economic activity."

${ }^{3}$ So-called threshold values pertaining to labour standards are one prominent example of regulations which become more extensive for larger firms. Dietrich and Junker (2003) document about 160 threshold levels in German labour law.
} 
'bribes' and assumed to be constant. The number of permits $\mathrm{x}$ acquired illegally will subsequently be interpreted as the extent of corruptive activities.

The assumptions on the functions $\mathrm{p}(\mathrm{k})$ and $\mathrm{C}(\mathrm{p}(\mathrm{k}))$ ensure $\partial \mathrm{C} / \partial \mathrm{k}>0$ and $\partial^{2} \mathrm{C} / \partial \mathrm{k}^{2}=\mathrm{C}^{\prime \prime}\left(\mathrm{p}^{\prime}\right)^{2}+$ $\mathrm{C}^{\prime} \mathrm{p} ">0$ and, hence, that the total costs of fulfilling the regulatory requirement increase at an increasing rate with capital. If, in contrast, the costs $\mathrm{C}(\mathrm{p}(\mathrm{k}))$ of obtaining permits legally were concave in $\mathrm{k}$, the incentives to obtain them legally would rise with firm size. Hence, large firms would be less likely to engage in corruptive behaviour. Since there is no evidence on the exact curvature of $\mathrm{C}$, it is assumed that the sufficient condition for corruption to exist in equilibrium is warranted. Moreover, while the number $\mathrm{p}(\mathrm{k})$ of permits required and their costs $\mathrm{C}(\mathrm{p}(\mathrm{k}))$ are likely to exhibit discontinuities, as usual in the analysis of variables which are not varied marginally in reality, in the model infinitesimal changes are assumed to be feasible.

Capital can be bought at a price $r$ per unit. Thus, profits in the absence of taxes and corruption are $R(k)-C(p(k))$, where $R(k):=f(k)$ - rk, denoted as net revenues, has been substituted for notational convenience, so that $\mathrm{R}^{\prime}(\mathrm{k})>-\mathrm{r}, \mathrm{R}^{\prime \prime}(\mathrm{k})<0$ for $\mathrm{k}>0, \mathrm{R}(0)=0$ and $\mathrm{R}^{\prime}(0) \rightarrow \infty$. Firms have to pay a proportional tax $\tau$ on profits but can evade taxes by under-declaring their gross profits $\mathrm{R}(\mathrm{k})-\mathrm{C}(\mathrm{p}(\mathrm{k})-\mathrm{x})-\mathrm{bx}$. Let $\mathrm{h}, 0 \leq \mathrm{h} \leq 1$, be the share of gross profits declared to tax authorities. The optimal declaration $\mathrm{h}^{*}$ depends, inter alia, on the tax treatment of bribes, via its impact on the costs of evasion. The parameter $\alpha, 0 \leq \alpha \leq 1$, measures the fraction of the expenditure bx for purchasing permits illegally which is tax deductible. Even if bribes are not tax deductible, as the OECD already suggested in 1996, bribe-related costs which also arise in the course of legal transactions may be fully deductible. Accordingly, a positive value of the parameter $\alpha$ represents a reasonable hypothesis and the tax base then equals $R(k)-C(p(k)-$ $\mathrm{x})-\alpha b x$.

The costs $\mathrm{K}$ of tax evasion may, inter alia, be determined by the extent of tax evasion, the probability of being detected and fined for evasion, the magnitude of penalties and the costs of audits and tax advisors. For simplicity, the strictly convex 'cost of evasion' function K, K', $\mathrm{K}^{\prime \prime}>0$, is presumed to depend on unpaid taxes $\tau[R(k)-C(p(k)-x)-\alpha b x]-\tau h[R(k)-C(p(k)$ $-\mathrm{x})$ - bx] only. ${ }^{4}$ Using all of the above assumptions, after-tax profits $\pi$ can be expressed as:

$$
\pi(k, x, h)=(1-\tau h)[R(k)-C(p(k)-x)-b x]-K(\tau[R(k)-C(p(k)-x)](1-h)-\tau b x(\alpha-h))(1)
$$

\footnotetext{
${ }^{4}$ If $\mathrm{K}$ depends on undeclared profits, the only effect of this modification will be that a higher tax rate has an ambiguous impact on the level of evasion, while tax evasion will decline if $\mathrm{K}$ is a function of unpaid taxes, as assumed above. This finding for income taxes (cf. Yitzhaki 1974) carries over to profit taxation for convex costs of evasion.
} 


\subsection{Optimal Choices}

The first-order conditions for the maximisation of after-tax profits $\pi$ are:

$$
\begin{gathered}
\frac{\partial \pi}{\partial \mathrm{k}}=\left(1-\tau \mathrm{h}-\mathrm{K}^{\prime}(\cdot) \tau(1-\mathrm{h})\right)\left(\mathrm{R}^{\prime}(\cdot)-\mathrm{C}^{\prime}(\cdot) \mathrm{p}^{\prime}(\cdot)\right)=0 \\
\frac{\partial \pi}{\partial \mathrm{x}}=(1-\tau \mathrm{h})\left(\mathrm{C}^{\prime}(\cdot)-\mathrm{b}\right)-\mathrm{K}^{\prime}(\cdot) \tau\left[(1-\mathrm{h}) \mathrm{C}^{\prime}(\cdot)-\mathrm{b}(\alpha-\mathrm{h})\right]=0 \\
\frac{\partial \pi}{\partial \mathrm{h}}=\left(-1+\mathrm{K}^{\prime}(\cdot)\right)[\mathrm{R}(\cdot)-\mathrm{C}(\cdot)-\mathrm{bx}]=0
\end{gathered}
$$

The expression in square brackets in (2c) is positive, since otherwise after-tax profits $\pi$ would be negative. Thus, an interior solution to the tax evasion problem, $0<\mathrm{h} *<1$, implies:

$$
\pi_{\mathrm{h}}:=-1+\mathrm{K}^{\prime}[\tau([\mathrm{R}(\mathrm{k})-\mathrm{C}(\mathrm{p}(\mathrm{k})-\mathrm{x})](1-\mathrm{h})-\mathrm{bx}(\alpha-\mathrm{h}))]=0
$$

Using $\left(2 c^{\prime}\right)$ in $(2 a)$ and $(2 b)$ yields:

$$
\begin{aligned}
& \pi_{\mathrm{k}}:=\mathrm{R}^{\prime}(\mathrm{k})-\mathrm{C}^{\prime}(\mathrm{p}(\mathrm{k})-\mathrm{x}) \mathrm{p}^{\prime}(\mathrm{k})=0 \\
& \pi_{\mathrm{X}}:=(1-\tau) \mathrm{C}^{\prime}(\mathrm{p}(\mathrm{k})-\mathrm{x})-\mathrm{b}(1-\alpha \tau)=0
\end{aligned}
$$

An inspection of equations $\left(2 a^{\prime}\right)$ and (2b') shows that the optimal choices of capital input $\mathrm{k}^{*}>0$ and permits $\mathrm{x}^{*}>0$ acquired illegally are independent of tax evasion. Since the parameter $\alpha$ never exceeds unity, the increase in gross profits $C^{\prime}(\cdot)$ of illegally purchasing an additional permit will generally be larger than the net-of-tax costs $b$ of doing so $\left(C^{\prime}(\cdot) \geq b\right)$.

While it has implicitly been assumed so far that the number of permits required is an increasing function of inputs, the regulatory requirement may also be related to output $f(k)$. In such a setting, the costs of acquiring permits would equal $\mathrm{C}(\mathrm{p}(\mathrm{f}(\mathrm{k}))-\mathrm{x})$ and profits be given by:

$$
\begin{aligned}
& \pi^{\#}(\mathrm{k}, \mathrm{x}, \mathrm{h})=(1-\tau \mathrm{h})[\mathrm{f}(\mathrm{k})-\mathrm{rk}-\mathrm{C}(\mathrm{p}(\mathrm{f}(\mathrm{k}))-\mathrm{x})-\mathrm{bx}] \\
&-\mathrm{K}(\tau[\mathrm{f}(\mathrm{k})-\mathrm{rk}-\mathrm{C}(\mathrm{p}(\mathrm{f}(\mathrm{k}))-\mathrm{x})](1-\mathrm{h})-\tau \mathrm{bx}(\alpha-\mathrm{h}))\left(1^{\#}\right)
\end{aligned}
$$

Maximising $\pi^{\#}$ with respect to $k, x$, and $h$ and rearranging yields $\left(2 \mathrm{a}^{\prime}\right)$ to $\left(2 \mathrm{c}^{\prime}\right)$ as first-order conditions, given $\mathrm{C}=\mathrm{C}(\mathrm{p}(\mathrm{f}(\mathrm{k}))-\mathrm{x})$. Therefore, the subsequent results will also apply if the regulatory requirement is related to the firm's output - instead of its inputs $\mathrm{k}$ - and the functions $\mathrm{p}(\mathrm{k})$ and $\mathrm{C}(\mathrm{p}(\mathrm{f}(\mathrm{k}))$ are sufficiently convex to ensure an interior profit maximum. 
Totally differentiating $\left(2 \mathrm{a}^{\prime}\right)$ to $\left(2 \mathrm{c}^{\prime}\right)$ for $\mathrm{C}(\mathrm{p}(\mathrm{k})$ - $\mathrm{x})$ with respect to the endogenous variables $\mathrm{k}$, $\mathrm{x}$, and $\mathrm{h}$, and a catch-all exogenous variable $\theta$, and using $\pi_{\mathrm{kh}}=\pi_{\mathrm{hk}}=\pi_{\mathrm{xh}}=0$, yields:

$$
\left[\begin{array}{ccc}
\pi_{\mathrm{kk}} & \pi_{\mathrm{kx}} & 0 \\
\pi_{\mathrm{xk}} & \pi_{\mathrm{xx}} & 0 \\
0 & \pi_{\mathrm{hx}} & \pi_{\mathrm{hh}}
\end{array}\right]\left[\begin{array}{c}
\mathrm{dk} \\
\mathrm{dx} \\
\mathrm{dh}
\end{array}\right]=\left[\begin{array}{c}
\pi_{\mathrm{k} \theta} \\
\pi_{\mathrm{x} \theta} \\
\pi_{\mathrm{h} \theta}
\end{array}\right][-\mathrm{d} \theta]
$$

Subsequently, arguments of the functions $\mathrm{R}, \mathrm{K}$ and $\mathrm{p}$ will be omitted for notational convenience. Since $\pi_{\mathrm{kx}}=\mathrm{C}^{\prime \prime} \mathrm{p}^{\prime}>0, \pi_{\mathrm{xx}}=-\mathrm{C}^{\prime \prime}(1-\tau)=-\pi_{\mathrm{xk}} / \mathrm{p}^{\prime}<0$, and $\pi_{\mathrm{kk}}, \pi_{\mathrm{hh}}<0$, the optimal choices $\mathrm{k}^{*}, \mathrm{x}^{*}$, and $\mathrm{h} *$ constitute a unique after-tax profit maximum (see Appendix 1). For later use it is helpful to note that $\pi_{h x}=K^{\prime \prime} \tau\left(C^{\prime}(1-h)-(\alpha-h) b\right) \geq 0$, as $C^{\prime} \geq b$ and $\alpha \leq$ 1 , and $\mathrm{D}:=\pi_{\mathrm{hh}}\left(\pi_{\mathrm{kk}} \pi_{\mathrm{Xx}}-\pi_{\mathrm{Xk}} \pi_{\mathrm{kX}}\right)<0$.

\section{Impact of Tax Evasion on Corruption}

The analysis of Section 2 has clarified that tax evasion, corruption, and input choices are separable to some extent. Therefore, it is possible to make statements about the impact of tax evasion on corruption (in this section) directly. However, since tax evasion and corruption are both determined endogenously, the impact of variations in exogenous parameters can shed more light on the correlation between evasion and corruption and is looked at in the next section. The effects of tax evasion on corruption and capital input choices are summarised in:

\section{Proposition 1}

(1) A firm uses the same amount of capital and purchases the same number of permits illegally, irrespective of the extent of tax evasion.

(2) The impact of anti-corruption policies on optimal corruption and capital input choices is unaffected by tax evasion activities.

Proof: Optimal choices of capital and permits purchased illegally are determined by equations $\left(2 a^{\prime}\right)$ and $\left(2 b^{\prime}\right)$. Neither of these equations depends on the optimal fraction $h^{*}$ of the tax base declared to tax authorities, proving part (1) of the Proposition. Moreover, the consequences of changes in any exogenous variable $\theta$ on capital and corruption choices are given by:

$$
\begin{aligned}
& \frac{\mathrm{dk}}{\mathrm{d} \theta}=\frac{\pi_{\mathrm{kx}} \pi_{\mathrm{x} \theta}-\pi_{\mathrm{k} \theta} \pi_{\mathrm{xx}}}{\pi_{\mathrm{kk}} \pi_{\mathrm{xx}}-\pi_{\mathrm{kx}} \pi_{\mathrm{xk}}} \\
& \frac{\mathrm{dx}}{\mathrm{d} \theta}=\frac{\pi_{\mathrm{xk}} \pi_{\mathrm{k} \theta}-\pi_{\mathrm{x} \theta} \pi_{\mathrm{kk}}}{\pi_{\mathrm{kk}} \pi_{\mathrm{xx}}-\pi_{\mathrm{kx}} \pi_{\mathrm{xk}}}
\end{aligned}
$$


Since none of the derivatives contained in equations (4) is affected by a variation in $\mathrm{h}^{*}$ (cf. equations (2a'), (2c'), and the calculations subsequent to (3)), the variations in capital input and corruption due to changes in exogenous variables aimed at combating corruption will be unaffected by tax evasion. This proves part (2) of the Proposition.

\section{Remarks}

Equations (2a') to $\left(2 c^{\prime}\right)$ illustrate that capital and corruption choices are independent of the level of tax evasion. In addition, any policy which alters the gains and costs of corruption will not be affected by the existence and extent of tax evasion. This is because even though anticorruption policies may affect tax evasion - an issue to be looked at in the next section - there are no repercussions on capital and corruption via a change in evasion activities. Moreover, capital choices do not alter optimal evasion decisions, that is, capital input and evasion choices are entirely separable, for a given amount of corruption. ${ }^{5}$ This two-directional independence arises because the marginal costs of tax evasion are unrelated to the level of capital input, given optimal capital choices, as $\partial \mathrm{K}^{\prime} / \partial \mathrm{K}^{*}=0$. The independence of corruption from optimal evasion choices holds irrespective of the tax treatment of bribes. This is the case as the marginal costs of evasion due to lower tax base declarations $\left(\partial \mathrm{K} / \partial \mathrm{h}^{*}\right)$ are independent of the extent of tax deductibility of bribes. Solely the level of evasion costs declines with the measure of tax deductibility $\alpha$.

According to Proposition 1 there is no impact of tax evasion on corruption, for given levels of other variables. However, if tax rates are the same in an economy with tax evasion and in another without evasion activities, so that capital and corruption choices coincide, tax revenues per firm will be less in the economy characterised by evasion. Suppose that the government in this economy increases the tax rate $\tau$ to a level so that the effective tax rate $\tau \mathrm{h}^{*}$ matches the (effective) tax rate $\tau$ in the economy without evasion. The impact of tax evasion on economic activity is summarised in:

\section{Proposition 2}

If revenue losses due to tax evasion are compensated by higher tax rates and if bribes are not completely tax deductible, tax evasion will reduce capital input and corruption.

Proof: As capital input and corruption are independent of evasion, the capital and corruption effects of imposing the same effective tax rate on firms in an economy with evasion as in an economy without such behaviour are solely due to the increase in the tax rate. The impact of

\footnotetext{
${ }^{5}$ For according results and also exceptions see Yaniv (1995, 1996), Lee (1998), and Panteghini (2000), inter alia.
} 
an increase in the profit tax rate $\theta=\tau$ on the first-order conditions (2a') and (2b') is given by $\pi_{\mathrm{k} \tau}=0$ and $\pi_{\mathrm{x} \tau}=-\left(\mathrm{C}^{\prime}-\alpha \mathrm{b}\right) \leq 0$. Since $\pi_{\mathrm{kk}}<0$ and $\pi_{\mathrm{kx}}>0$, the changes in $\mathrm{k}^{*}$ and $\mathrm{x}^{*}$ are:

$$
\frac{\mathrm{dk} *}{\mathrm{~d} \tau}=-\frac{\pi_{\mathrm{kx}} \pi_{\mathrm{hh}}\left(\mathrm{C}^{\prime}-\alpha \mathrm{b}\right)}{\mathrm{D}}=-\frac{\mathrm{dx} *}{\mathrm{~d} \tau} \frac{\pi_{\mathrm{kx}}}{\pi_{\mathrm{kk}}} \leq 0
$$

\section{Remarks}

An increase in the profit tax rate $\tau$ does not alter capital choices directly but reduces corruption, unless bribes are fully tax deductible. The higher the tax rate, the lower the relative costs of acquiring a given amount of permits legally. Since such costs are fully tax deductible, a tax rate increase raises the costs of bribes to a greater extent than expenditure of purchasing them legally, as long as bribes are not fully tax deductible. Hence, the incentives to acquire permits legally become stronger. This induces less corruption and the marginal costs of capital rise. As the resulting reduction in capital usage is conditional on the change in corruption, it will only occur if bribes are not fully tax deductible.

The findings summarised in Propositions 1 and 2 suggest that there is either no or a negative indirect - correlation between tax evasion and corruption. However, a direct impact of tax evasion activities on corruption activities is not discernible.

\section{Combating Corruption}

Section 3 has shown that the extent of corruption is independent of tax evasion activities. However, this independence is unidirectional in the basic model, unless bribes are fully tax deductible $(\alpha=1)$, as the marginal gains from honesty - or costs of evasion - $\pi_{\mathrm{h}}$ rise with the number of permits $\mathrm{x}$ purchased illegally (i.e. $\pi_{\mathrm{hx}}>0$ for $\alpha<1$ ). This increase in the marginal costs $\mathrm{K}^{\prime}$ of evasion occurs because more bribes raise actual costs by the full amount of bribes while tax deductible costs only increase by a fraction $\alpha<1$. Given the influence of corruption on tax evasion, it is analysed subsequently how parameters which are primarily intended to reduce corruption activities change corruption, capital and tax evasion.

First, a reduction in the measure of the tax deductibility $\alpha$ of the costs of purchasing permits illegally is investigated. While the explicit costs of domestic bribes have generally not been tax deductible, this was not necessarily true for bribes paid abroad. Only recently the OECD's anti-bribery convention required signatory countries to make bribes to foreign officials a criminal offence. The legislative changes resulting from the OECD's convention can, therefore, be interpreted as a reduction in the measure of tax deductibility $\alpha$. Moreover, the 
costs of purchasing permits do not only result from explicit bribes, as the choice of words in the present context may suggest. The 'bribe' can also contain the costs of legal advice, regular business expenses incurred in the course of purchasing permits or the costs of activities aimed at hiding corruptive behaviour. Such costs are often fully tax deductible since they are hard to distinguish from similar expenses incurred while pursuing legal objectives. A reduction in the measure of tax deductibility $\alpha$ can, thus, also be interpreted as a more extensive definition of expenses due to corruption activities which are not tax deductible. Second, an increase in unit costs $b$ of purchasing permits is analysed. These costs can go up, for example, if the fine imposed on risk-averse bureaucrats for accepting bribes, the probability of being punished or their wages rise, implying a reduction in the net gain from accepting a bribe of a given magnitude. As a consequence, the bribe b will grow, since the 'supply curve' for illegally obtained permits shifts upwards. Third, corruption can be combated indirectly by reducing the number of permits per unit of capital $\mathrm{p}(\mathrm{k})$ required for production. As an alternative respectively in addition - a fall in the number of permits per unit of capital at the margin $p^{\prime}(k)$ can be considered. These policy measures reduce the regulatory requirements and, hence, the need for corruptive activities. ${ }^{6}$

The impact of a reduction in the tax deductibility $\alpha$ of the costs of purchasing permits illegally is summarised in:

\section{Proposition 3}

A reduction in the tax deductibility of the costs of permits purchased illegally lowers capital input and corruption. The effect on tax evasion is ambiguous, unless an initial situation of full deductibility $(\alpha=1)$ is considered, in which case tax evasion declines.

Proof: The impact of an increase in $\alpha$ on (2a') to (2c') is given by $\pi_{\mathrm{k} \alpha}=0, \pi_{\mathrm{x} \alpha}=\mathrm{b} \tau>0, \pi_{\mathrm{h} \alpha}=$ $-\mathrm{K}^{\prime \prime} \tau \mathrm{bx} *<0$. Using $\pi_{\mathrm{kk}}, \pi_{\mathrm{hh}}<0, \pi_{\mathrm{kx}}>0, \pi_{\mathrm{hx}} \geq 0$, the results enumerated subsequent to equation (3), and $\mathrm{D}<0$, the changes in $\mathrm{k}^{*}, \mathrm{x}^{*}$, and $\mathrm{h}^{*}$ are found to be:

$$
\begin{gathered}
\frac{\mathrm{dk}^{*}}{\mathrm{~d} \alpha}=\frac{\pi_{\mathrm{kx}} \pi_{\mathrm{hh}} \mathrm{b} \tau}{\mathrm{D}}=-\frac{\mathrm{dx} *}{\mathrm{~d} \alpha} \frac{\pi_{\mathrm{kx}}}{\pi_{\mathrm{kk}}}>0 \\
\frac{\mathrm{dh} *}{\mathrm{~d} \alpha}=\frac{-\pi_{\mathrm{kk}}\left(\pi_{\mathrm{xx}} \pi_{\mathrm{h} \alpha}-\pi_{\mathrm{hx}} \pi_{\mathrm{x} \alpha}\right)+\pi_{\mathrm{kx}} \pi_{\mathrm{xk}} \pi_{\mathrm{h} \alpha}}{\mathrm{D}}
\end{gathered}
$$

\footnotetext{
${ }^{6}$ Finally, a change in tax rates could be analysed. However, the impact of tax rate variations on evasion activities depends crucially on whether the costs of evasion are a function of evaded taxes or undeclared income (cf. footnote 4). Therefore, any correlation between tax evasion and corruption owing to tax rate changes is modelspecific and will not be looked at further.
} 


$$
=\frac{\mathrm{bx} * \mathrm{~K}^{\prime \prime} \tau}{\mathrm{D}} \pi_{\mathrm{kk}}\left[\mathrm{C}^{\prime}\left(1-\mathrm{h}^{*}\right)-(\alpha-\mathrm{h} *) \mathrm{b}\right]-\frac{\pi_{\mathrm{h} \alpha}}{\pi_{\mathrm{hh}}}
$$

The term in square brackets in (6b) is positive, unless $\alpha=1$ applies (cf. equation ( $\left.2 b^{\prime}\right)$ ), while the last term is unambiguously positive and deducted. If $\alpha=1, \mathrm{dh} * / \mathrm{d} \alpha<0$ will hold as $\mathrm{C}^{\prime}=\mathrm{b}$. Since a decrease in $\alpha$ is looked at, $\mathrm{h} *$ rises and tax evasion declines.

\section{Remarks}

If (illegally) purchasing a permit reduces the tax burden by less than before the change in policy (because $\alpha$ declines), the costs of corruption will rise and fewer permits will be acquired illegally. The decline in $x^{*}$ raises the marginal costs of obtaining the required number of permits officially $\mathrm{C}^{\prime}\left(\mathrm{p}\left(\mathrm{k}^{*}\right)-\mathrm{x}^{*}\right)$, given $\mathrm{C}^{\prime \prime}>0$, and, thereby, also the marginal costs of capital. Optimal capital usage declines.

The effect of a reduction in the tax deductibility of bribes on tax evasion is twofold: first, the marginal costs of tax evasion $\mathrm{K}^{\prime}$ rise with a decline in $\alpha$, as $\pi_{\mathrm{h} \alpha}<0$ indicates. This c. $\mathrm{p}$. reduces evasion. The first-order condition (2b') shows that, second, the marginal costs of bribery rise, because the effective tax rate on permits purchased illegally goes up. Fewer bribes, however, lower the costs of tax evasion which c. p. increases. The marginal cost effect of a variation in the tax deductibility is due to differential effective tax rates on permits purchased illegally $(1-\alpha \tau)$ and on the costs of acquiring permits legally $(1-\tau)$. Accordingly, the marginal cost effect will not arise if effective tax rates are identical, that is if full deductibility is assumed.

The impact of a higher bribe b on capital input, tax evasion and corruption is summarised as:

\section{Proposition 4}

A higher bribe $b$ reduces capital input and corruption. Tax evasion always rises for $\alpha \geq h *$.

Proof: The consequences of an increase in b on the first-order conditions (2a') to (2c') are given by $\pi_{\mathrm{kb}}=0, \pi_{\mathrm{xb}}=-(1-\tau \alpha)<0, \pi_{\mathrm{hb}}=-\mathrm{K}^{\prime \prime} \tau \mathrm{x} *\left(\alpha-\mathrm{h}^{*}\right)$. Since $\pi_{\mathrm{kk}}, \pi_{\mathrm{hh}}<0, \pi_{\mathrm{hx}} \geq 0, \pi_{\mathrm{kx}}$ $>0$, and $\mathrm{D}<0$, the changes in $\mathrm{k}^{*}, \mathrm{x}^{*}$, and $\mathrm{h}^{*}$ are:

$$
\begin{gathered}
\frac{\mathrm{dk} *}{\mathrm{db}}=-\frac{\pi_{\mathrm{kx}} \pi_{\mathrm{hh}}(1-\alpha \tau)}{\mathrm{D}}=-\frac{\mathrm{dx} *}{\mathrm{db}} \frac{\pi_{\mathrm{kx}}}{\pi_{\mathrm{kk}}}<0 \\
\frac{\mathrm{dh} *}{\mathrm{db}}=-\frac{\mathrm{x}^{*} \mathrm{~K}^{\prime \prime} \tau \mathrm{C}^{\prime \prime}(1-\tau)\left(\alpha-\mathrm{h}^{*}\right)}{\mathrm{D}}\left[\mathrm{R}^{\prime \prime}-\mathrm{C}^{\prime} \mathrm{p}^{\prime \prime}\right]-\frac{\pi_{\mathrm{kk}} \pi_{\mathrm{hx}}(1-\alpha \tau)}{\mathrm{D}}
\end{gathered}
$$




\section{Remarks}

A higher bribe has no direct impact on the costs of capital. However, purchasing permits illegally becomes more expensive and, hence, fewer bribes are paid. Since less corruption raises the marginal costs of capital, capital input declines. The direct effect of bribes on tax evasion is uncertain, since the marginal gain of declaring profits to tax authorities, i.e. the marginal costs of evasion, will only fall with a greater expenditure for bribes if $\alpha>h *$ holds. In such a situation, taxable income declines by more than the amount of taxes evaded. Given a fall in the gain from tax honesty, declared income is reduced and evasion rises. Apart from this direct effect, the decline in the number of permits purchased illegally lowers undeclared income and the marginal gain from honest tax declarations $\mathrm{K}^{\prime}$. This indirect impact unambiguously raises tax evasion. Since the direct and the indirect consequences cannot be compared quantitatively, the relationship between bribes and tax evasion will be an unambiguously positive one only if the two effects do not work in opposite directions.

Finally, the government may reduce the scope for corruption by cutting down the number of permits $\mathrm{p}(\mathrm{k})$ required per unit of capital and/or the number of permits needed for an additional unit of capital $\mathrm{p}^{\prime}(\mathrm{k})$. The respective findings for such a policy are summed up in:

\section{Proposition 5}

(1) A decrease in the absolute number of permits required does not alter capital input, but lowers corruption and also tax evasion if $\alpha>h^{*}$, for a given marginal number $\mathrm{p}^{\prime}(\mathrm{k})$ of permits. (2) A decrease in the number of permits required for an additional unit of capital raises capital input and alters neither corruption nor tax evasion, for a given absolute number $\mathrm{p}(\mathrm{k})$ of permits.

(3) A combined reduction in the absolute and marginal number of permits required raises capital input and lowers corruption and also tax evasion if $\alpha>h^{*}$.

Proof: The effects of an increase in $\mathrm{p}(\mathrm{k})\left(\mathrm{p}^{\prime}(\mathrm{k})\right)$ on the first-order conditions (2a') to $\left(2 \mathrm{c}^{\prime}\right)$, for a constant marginal (absolute) number of permits $\mathrm{p}^{\prime}(\mathrm{k})(\mathrm{p}(\mathrm{k}))$ required, are given by $\pi_{\mathrm{kp}}=-\mathrm{C}^{\prime \prime} \mathrm{p}^{\prime}$ $<0, \pi_{\mathrm{xp}}=\mathrm{C}^{\prime \prime}(1-\tau)>0, \pi_{\mathrm{hp}}=-\mathrm{K}^{\prime \prime} \tau \mathrm{C}^{\prime}\left(1-\mathrm{h}^{*}\right)<0, \pi_{\mathrm{kp}}=-\mathrm{C}^{\prime}<0, \pi_{\mathrm{xp}}=\pi_{\mathrm{hp}}=0$. As $\pi_{\mathrm{xx}}, \pi_{\mathrm{hh}}$

$<0, \pi_{\mathrm{hx}} \geq 0, \pi_{\mathrm{kx}}>0, \pi_{\mathrm{xk}}=0$ and $\pi_{\mathrm{kk}}=\mathrm{R}^{\prime \prime}-\mathrm{C}^{\prime} \mathrm{p} "$ for $\mathrm{dp}(\mathrm{k})=0$, and $\pi_{\mathrm{kk}}=\mathrm{R}^{\prime \prime}-\mathrm{C}^{\prime \prime}\left(\mathrm{p}^{\prime}\right)^{2}$ for $\mathrm{dp}^{\prime}(\mathrm{k})=0$, the changes in $\mathrm{k}^{*}, \mathrm{x}^{*}$, and $\mathrm{h}^{*}$ are given by $\mathrm{dk} * / \mathrm{dp}=\mathrm{dx}^{*} / \mathrm{dp}^{\prime}=\mathrm{dh}^{*} / \mathrm{dp}^{\prime}=0$ and:

$$
\frac{\mathrm{dk}^{*}}{\mathrm{dp}^{\prime}}=\frac{\pi_{\mathrm{xx}} \pi_{\mathrm{hh}} \mathrm{C}^{\prime}}{\mathrm{D}(\mathrm{dp}(\mathrm{k})=0)}<0
$$




$$
\begin{aligned}
& \frac{d x^{*}}{d p}=-\frac{(1-\tau) C^{\prime \prime}\left(R^{\prime \prime}-C^{\prime} p^{\prime \prime}\right) \pi_{h h}}{D\left(d p^{\prime}(k)=0\right)}=1 \\
& \frac{d h^{*}}{d p}=-\frac{K^{\prime \prime} \tau C^{\prime \prime}(1-\tau) R^{\prime \prime}\left(\alpha-h^{*}\right) b}{D\left(d p^{\prime}(k)=0\right)},
\end{aligned}
$$

where $\mathrm{D}\left(\mathrm{dp}^{\prime}(\mathrm{k})=0\right):=-\pi_{\mathrm{hh}} \mathrm{R}^{\prime \prime} \mathrm{C}^{\prime \prime}(1-\tau)<0$ and $\mathrm{D}(\mathrm{dp}(\mathrm{k})=0):=-\pi_{\mathrm{hh}}\left(\mathrm{R}^{\prime \prime}-\mathrm{C}^{\prime} \mathrm{p}^{\prime \prime}\right) \mathrm{C}^{\prime \prime}(1-\tau)<0$.

Combining a fall in the absolute and marginal number of permits required $\mathrm{p}(\mathrm{k})$ and $\mathrm{p}^{\prime}(\mathrm{k})$ results in more capital input, since $\mathrm{dk}^{*} / \mathrm{dp}(\mathrm{k})+\mathrm{dk}^{*} / \mathrm{dp}^{\prime}(\mathrm{k})<0$. The results for tax evasion and corruption can be determined in analogy.

\section{Remarks}

Inspection of the first-order conditions $\left(2 a^{\prime}\right)$ to $\left(2 c^{\prime}\right)$ reveals that a decline in the number of permits required $\mathrm{p}(\mathrm{k})$, holding constant the marginal prerequisite, reduces the costs of obtaining an additional permit legally $\mathrm{C}^{\prime}\left(\mathrm{p}\left(\mathrm{k}^{*}\right)-\mathrm{x}^{*}\right)$, which are determined by the first-order condition for the optimal selection of bribes $\left(2 b^{\prime}\right)$. This is the case because the net-of-tax marginal costs of purchasing permits are constant, given optimal evasion choices. Thus, also the marginal gain must be constant. Accordingly, any fall in the number of permits required $\mathrm{p}(\mathrm{k})$ has to be compensated by a reduction in the number of permits $\mathrm{x}^{*}$ obtained illegally of exactly the same magnitude. Corruption declines. However, if the number of permits purchased illegally is reduced by exactly the same extent as the number of permits required has fallen, marginal costs of capital will remain unaffected and capital input will not vary. Finally, constant costs of capital $\mathrm{C}\left(\mathrm{p}\left(\mathrm{k}^{*}\right)-\mathrm{x}^{*}\right)-\mathrm{rk}^{*}$ and fewer permits purchased illegally imply a greater undeclared tax base $\left(\mathrm{R}\left(\mathrm{k}^{*}\right)-\mathrm{C}\left(\mathrm{p}\left(\mathrm{k}^{*}\right)-\mathrm{x}^{*}\right)\right)\left(1-\mathrm{h}^{*}\right)-\mathrm{bx} *\left(\alpha-\mathrm{h}^{*}\right)$ for $\alpha>\mathrm{h}^{*}$, entailing a larger gain from truthful declarations. Hence, tax evasion will fall if $\alpha>h^{*}$.

A decrease in the marginal number of permits required $\mathrm{p}^{\prime}\left(\mathrm{k}^{*}\right)$ lowers the marginal costs of capital and raises capital input. The first-order conditions for the choice of tax evasion and corruption activities are independent of $\mathrm{p}^{\prime}(\mathrm{k})$. Since the absolute number of permits is held constant by assumption, tax evasion and corruption do not change.

The findings may be summed up as follows: Corruption can be diminished if the tax deductibility of bribes is reduced, the costs of acquiring a permit illegally are raised, or the number of permits required for production is lowered. With the exception of a reduction in the number of permits required, which also lowers tax evasion (for $\alpha>h^{*}$ ), all other policy measures which reduce corruption either affect tax evasion in an ambiguous manner or 
actually raise it. Policies to fight corruption are, thus, no suitable instruments to raise the fraction of the tax base declared to tax authorities in the framework under consideration. ${ }^{7}$

This evaluation will be strengthened further if the impact of anti-corruption policies on the government budget is taken into account. Higher costs of purchasing permits illegally decrease the tax base, while a reduced tax deductibility of bribes and fewer permits required for production raise the tax base. In addition, the amount of taxes evaded varies, often in an uncertain direction. Finally, anti-corruption policies are unlikely to be costless, so that the impact of such policy measures on the government's budget cannot be predicted without making further assumptions with respect, for example, to the measure of tax deductibility of bribes $\alpha$ or the costs of anti-corruption policies. ${ }^{8}$ Therefore, the change in the tax rate which warrants a balanced budget cannot be ascertained either and incorporating the budgetary effects of anti-corruption policies into the analysis of combating corruption in the presence of tax evasion aggravates the uncertainty regarding this relationship.

\section{Alternative Objectives}

In the analysis of tax evasion behaviour it has been shown that some findings are sensitive to the exact specifications of the evasion technology and the 'cost of evasion' function. ${ }^{9}$ Martinez-Vazquez and Rider (2005), for example, demonstrate that the comparative static effects in a model of income tax evasion will become ambiguous if individuals have multiple modes of evading taxes, such as under-declaring gross income and overstating deductions. To investigate the robustness of the findings obtained thus far, suppose, first, that firms can declare differential fractions or multiples of the true tax bases for net revenues $\mathrm{R}(\mathrm{k})$, the costs of permits $\mathrm{C}(\mathrm{p}(\mathrm{k})-\mathrm{x})$ and bribe payments bx. Let the degree of truthful declaration of net revenues $R(k)$ be denoted by $h_{R}$, of the costs of permits by $h_{C}$ and of bribes by $h_{B}$. Differential choices can be beneficial for the firm if the 'cost of evasion' functions differ for the alternatives means of evading taxes. These cost functions are denoted by $\mathrm{K}_{\mathrm{R}}, \mathrm{K}_{\mathrm{C}}$, and

\footnotetext{
${ }^{7}$ This result is based on an optimal choice of evasion activities. As an anonymous referee has pointed out, this assumption is not innocuous, as the firm may be obliged to hide part of the profit from corruption and to evade more taxes than it would do in the absence of corruptive activities. If the measure of profit declarations is limited to $\overline{\mathrm{h}} \neq \mathrm{h}^{*}$, any statement about the correlation between corruption and tax evasion will depend on the assumptions with respect to the determinants of $\overline{\mathrm{h}}$. A setting in which tax evasion is restricted, thus allows for even less of a prediction about the link between the two types of illegal activities than a framework with optimal choices.

${ }^{8}$ Since profits are taxed and because capital input and corruption activities are chosen optimally, variations in capital and corruption have no first-order tax base impact.

${ }^{9}$ The investigation of the subsequent modifications has been suggested by the anonymous referees to whom I am extremely grateful for pointing out the insights of these extensions.
} 
$K_{B}$, and exhibit the same features as the function $K$, i.e. $K_{i}^{\prime}, K_{i}^{\prime \prime}>0$ for $i=R, C$, B. In such a setting, the firm's objective is given by:

$$
\begin{aligned}
\pi^{+}\left(\mathrm{k}, \mathrm{x}, \mathrm{h}_{\mathrm{R}}, \mathrm{h}_{\mathrm{C}}, \mathrm{h}_{\mathrm{B}}\right)= & \left(1-\tau_{\mathrm{R}}\right) \mathrm{R}(\mathrm{k})-\mathrm{K}_{\mathrm{R}}\left(\tau \mathrm{R}(\mathrm{k})\left(1-\mathrm{h}_{\mathrm{R}}\right)\right) \\
& -\left(1-\tau_{\mathrm{C}}\right) \mathrm{C}(\mathrm{p}(\mathrm{k})-\mathrm{x})-\mathrm{K}_{\mathrm{C}}\left(\tau[\mathrm{C}(\mathrm{p}(\mathrm{k})-\mathrm{x})]\left(\mathrm{h}_{\mathrm{C}}-1\right)\right) \\
& -\left(1-\tau_{\mathrm{B}}\right) \mathrm{bx}-\mathrm{K}_{\mathrm{B}}\left(\tau \mathrm{bx}\left(\mathrm{h}_{\mathrm{B}}-\alpha\right)\right)
\end{aligned}
$$

Second, it can be hypothesised that the true tax basis of firms is not affected by bribe payments, so that the 'cost of evasion' function $\mathrm{K}$ is independent of the extent of corruption. This specification is based on the notion that the tax authorities are aware of the costs of attaining permits legally and that bribes, therefore, do not reduce the tax base. If the firm chooses the share $\mathrm{h}$ of profits declared to tax authorities in such a setting, its objective will be:

$$
\pi^{++}(\mathrm{k}, \mathrm{x}, \mathrm{h})=\mathrm{R}(\mathrm{k})-\mathrm{C}(\mathrm{p}(\mathrm{k})-\mathrm{x})-\mathrm{bx}-\mathrm{h} \tau[\mathrm{R}(\mathrm{k})-\mathrm{C}(\mathrm{p}(\mathrm{k})]-\mathrm{K}(\tau[\mathrm{R}(\mathrm{k})-\mathrm{C}(\mathrm{p}(\mathrm{k})](1-\mathrm{h}))
$$

Focussing initially on the framework with multiple ways of evading taxes, assume that the firm can declare each tax base separately. Maximising $\pi^{+}$with respect to capital $\mathrm{k}$, the number of permits x purchased illegally, and $h_{i}, i=R, C, B$, then yields ( $\left.2 a^{\prime}\right)$ and ( $\left.2 b^{\prime}\right)$ as firstorder conditions as well as:

$$
\begin{aligned}
& \pi_{\mathrm{h}_{\mathrm{R}}}:=-1+\mathrm{K}_{\mathrm{R}}{ }^{\prime}\left[\tau \mathrm{R}(\mathrm{k})\left(1-\mathrm{h}_{\mathrm{R}}\right)\right]=0 \\
& \pi_{\mathrm{h}_{\mathrm{C}}}:=1-\mathrm{K}_{\mathrm{C}}{ }^{\prime}\left[\tau \mathrm{C}(\mathrm{p}(\mathrm{k})-\mathrm{x})\left(\mathrm{h}_{\mathrm{C}}-1\right)\right]=0 \\
& \pi_{\mathrm{h}_{\mathrm{B}}}:=1-\mathrm{K}_{\mathrm{B}}{ }^{\prime}\left[\tau \mathrm{bx}\left(\mathrm{h}_{\mathrm{B}}-\alpha\right)\right]=0
\end{aligned}
$$

Optimal interior choices of tax declarations imply $0<\mathrm{h}_{\mathrm{R}}^{*}<1, \mathrm{~h}_{\mathrm{C}}^{*}>1$ and $\mathrm{h}_{\mathrm{B}} * \alpha$. Such interior solutions are assumed for the subsequent exposition. ${ }^{10}$ In this modified framework, Proposition 1 and all findings of the basic model with respect to the optimal choice of capital $\mathrm{k}^{*}$ and the number of permits $\mathrm{x}^{*}$ acquired illegally, as summarised in Propositions 2 to 5, continue to hold. This is due to the separability of capital and corruption activities on the one hand and tax evasion choices on the other hand (cf. Proposition 1). However, tax evasion

\footnotetext{
${ }^{10}$ Proofs of the results of this section are relegated to Appendix 2. If bribes were not tax deductible, this would imply $\alpha=0$ and in the case of separate declarations also $h_{B}=0$ as tax evasion would otherwise immediately be recognised.
} 
decisions are not separable from the amount of capital used and the extent of corruption. The consequences of variations in exogenous variables on the various modes of tax evasion are summarised in table 1:

Table 1:

Direction of Change in Tax Base Declarations Due to an Increase in an Exogenous Variable

\begin{tabular}{|l|c|c|c|c|}
\hline & $\alpha$ & $\mathrm{b}$ & $\mathrm{p}(\mathrm{k})\left(\mathrm{dp}^{\prime}(\mathrm{k})=0\right)$ & $\mathrm{p}^{\prime}(\mathrm{k})(\mathrm{dp}(\mathrm{k})=0)$ \\
\hline $\mathrm{h}_{\mathrm{R}}{ }^{*}$ & $>0$ & $<0$ & 0 & $<0$ \\
\hline $\mathrm{h}_{\mathrm{C}}{ }^{*}$ & $<0$ & $>0$ & 0 & $>0$ \\
\hline $\mathrm{h}_{\mathrm{B}}{ }^{*}$ & $?$ & $?$ & $<0$ & $=0$ \\
\hline
\end{tabular}

A decrease in the tax deductibility $\alpha$ of bribes lowers capital input and corruption (cf. Proposition 3). Moreover, from equation (6a) it can be derived that $\mathrm{p}(\mathrm{k})-\mathrm{x}$ declines with a fall in $\alpha$. The first-order conditions $\left(2 \mathrm{c}^{+}\right)$and $\left(2 \mathrm{~d}^{+}\right)$then immediately reveal that the optimal fraction $\mathrm{h}_{\mathrm{R}}^{*}$ of net revenues $\mathrm{R}(\mathrm{k})$ declared to tax authorities falls with a decline in $\alpha$, whereas the over-declaration $\mathrm{h}_{\mathrm{C}}{ }^{*}$ of the costs of permits $\mathrm{C}(\mathrm{p}(\mathrm{k})-\mathrm{x})$ rises. The impact on the declaration of bribes is uncertain - indicated by the question mark in table $1-$, as inspection of $\left(2 \mathrm{e}^{+}\right)$reveals. This is the case as the decline in the number of permits $\mathrm{x}$ acquired illegally and the measure of tax deductibility $\alpha$ have opposite effects on the optimal declaration $\mathrm{h}_{\mathrm{B}}{ }^{*}$. The intuition for the effects of a higher bribe $b$ is the same, as it also reduces capital input and corruption (cf. Proposition 4).

A reduction in the absolute number $\mathrm{p}(\mathrm{k})$ of permits required for production, for a given requirement per additional unit of capital $\mathrm{p}^{\prime}(\mathrm{k})$, does not alter capital input and lowers corruption to an extent so that the costs $\mathrm{C}(\mathrm{p}(\mathrm{k})-\mathrm{x})$ of obtaining permits legally remain constant (cf. Proposition 5(1)). Accordingly, neither the fraction $\mathrm{h}_{\mathrm{R}}{ }^{*}$ of net revenues $\mathrm{R}(\mathrm{k})$ nor the over-declaration $\mathrm{h}_{\mathrm{C}}$ of the costs of obtaining permits legally change with a variation in the number of permits required (cf. equations $\left(2 c^{+}\right)$and $\left(2 d^{+}\right)$). However, less corruption reduces the costs of an over-declaration of bribe expenditure and the over-declaration rises. All three effects in combination imply a rise in tax evasion owing to a fall in the number of permits required. Finally, a lower number of permits $\mathrm{p}^{\prime}(\mathrm{k})$ required for an additional unit of capital, for a given absolute requirement $\mathrm{p}(\mathrm{k})$, raises capital input and does not affect the optimal amount of corruption (cf. Proposition 5(2)). If the extent of corruption remains 
constant, the incentives to over-declare bribes will be the same. Accordingly, $\mathrm{h}_{\mathrm{B}}$ * does not change. Greater capital usage raises the costs of insufficient revenue declarations and, therefore, $h_{R} *$ increases with a decline in $p^{\prime}(k)$. Higher costs $C(p(k)-x)$ of acquiring permits legally decrease the incentives to over-declare these costs, and $\mathrm{h}_{\mathrm{C}} *$ falls. Thus, a reduction in the number of permits required per additional unit of capital restricts tax evasion. A combined decline in the absolute and marginal number of permits has an ambiguous effect on tax evasion.

The above analysis clarifies that the effects of changes in the tax deductibility of bribes, the level of bribes and the regulatory environment on capital and corruption choices are not altered by the existence of multiple modes of tax evasion. However, the impact of variations in these exogenous variables on tax evasion may either become uncertain or can also actually be reversed in comparison to a setting with a single evasion variable $h$, as it is the case for a higher number of permits required.

Turning to the second alternative specification and maximising equation $\left(1^{++}\right)$with respect to capital $\mathrm{k}$, the number of permits $\mathrm{x}$ purchased illegally, and the share of profits $\mathrm{h}$ declared to tax authorities, yields:

$$
\begin{gathered}
\pi_{\mathrm{k}}:=\mathrm{R}^{\prime}(\mathrm{k})(1-\tau)-\left[\mathrm{C}^{\prime}(\mathrm{p}(\mathrm{k})-\mathrm{x})-\mathrm{C}^{\prime}(\mathrm{p}(\mathrm{k})) \tau\right] \mathrm{p}^{\prime}(\mathrm{k})=0 \\
\pi_{\mathrm{X}}:=\mathrm{C}^{\prime}(\mathrm{p}(\mathrm{k})-\mathrm{x})-\mathrm{b}=0 \\
\pi_{\mathrm{h}}:=-1+\mathrm{K}^{\prime}[\tau\{\mathrm{R}(\mathrm{k})-\mathrm{C}(\mathrm{p}(\mathrm{k}))\}(1-\mathrm{h})]=0
\end{gathered}
$$

Note that an interior solution for the tax evasion problem will be warranted only if net revenues $R(k)$ exceed the costs $C(p(k))$ of acquiring all permits legally. Since $p^{\prime}(k), R^{\prime}(k)>0$, an interior solution for the choice of capital $\mathrm{k}$ implies that the term in square brackets in $\left(2 \mathrm{a}^{++}\right)$is positive, $\left[\mathrm{C}^{\prime}(\mathrm{p}(\mathrm{k})-\mathrm{x})-\mathrm{C}^{\prime}(\mathrm{p}(\mathrm{k}) \tau]>0\right.$. Further inspection of the first-order conditions shows that the optimal levels of capital input and corruption are independent of tax evasion activities. Therefore, Proposition 1 holds in this modified framework as well. However, in contrast to the basic model of Section 2, tax evasion is not independent of capital choices, as $\partial \mathbf{K}^{\prime} / \partial \mathbf{k}^{*}>0$. Moreover, capital and corruption unambiguously fall with the tax rate, so that the findings summarised in Proposition 2 apply without the restriction on the tax deductibility of bribes. ${ }^{11}$ In addition, a higher bribe $\mathrm{b}$ reduces optimal capital input $\mathrm{k}^{*}$, the measure of corruption $\mathrm{x}^{*}$ and raises tax evasion since $\mathrm{dh} * / \mathrm{db}<0$. Comparing these findings with

\footnotetext{
${ }^{11}$ Obviously, no statement about the impact of a change in the tax deductibility of bribes (cf. Proposition 3 ) is feasible, since it does not play a role in the modified setting.
} 
Proposition 4 illustrates that the alteration of the analytical framework does not affect the consequences for capital and corruption choices and strengthens the prediction with respect to tax evasion since the decrease in $h^{*}$ no longer depends on the degree of tax deductibility. Finally, a decrease in the absolute number $\mathrm{p}(\mathrm{k})$ of permits required lowers capital input and corruption, and has uncertain consequences for the extent of tax evasion. A reduction in the number of permits $\mathrm{p}^{\prime}(\mathrm{k})$ required for an additional unit of capital raises capital input, corruption and tax evasion. Hence, the consequences of a combined fall in the absolute and marginal number of permits cannot be ascertained.

In comparison to the basic model of Section 2, the restrictions on the tax deductibility of bribes are not required to sign the consequences of an increase in the bribe $b$ on tax evasion, and of a rise in the tax rate on capital and corruption choices. This is the case since bribe payments do not affect the costs of tax evasion $\mathrm{K}$, for given choices of capital k. Moreover, optimal capital, corruption, and tax evasion choices generally vary in the modified model with a change in the absolute and marginal number of permits required, relative to the framework of Section 2. These changes are caused by the assumption that the costs of obtaining permits legally differ according to whether they affect gross profits $(\mathrm{C}(\mathrm{p}(\mathrm{k})-\mathrm{x}))$ or the tax base $(\mathrm{C}(\mathrm{p}(\mathrm{k})))$. Since these costs - and also marginal costs - are higher in terms of their impact on the tax base, as $\mathrm{C}(\mathrm{p}(\mathrm{k}))>\mathrm{C}(\mathrm{p}(\mathrm{k})-\mathrm{x})>0$ and $\mathrm{C}^{\prime}(\mathrm{p}(\mathrm{k})-\mathrm{x})-\mathrm{C}^{\prime}(\mathrm{p}(\mathrm{k}) \tau>0$, the incentives to evade taxes will be reduced, relative to the basic model of Section 2, if the number of permits $\mathrm{p}(\mathrm{k})$ required falls.

The analysis of the two extensions of the model proposed in Section 2 has illustrated that the impact of tax evasion on capital and corruption choices is basically unaffected by alternative assumptions regarding tax evasion technologies. However, the impact of variations in those exogenous variables which are primarily intended to lower corruption on tax evasion behaviour may change. Accordingly, the nature of the relationship between tax evasion and corruption may be altered by the modifications. In general, however, an indirect link between the two types of illegal activities continues to exist.

\section{Summary and Conclusions}

What is the relationship between corruption and tax evasion? Are countries plagued by corruption also characterised by more tax evasion activities, or is the linkage an inverse one? Do policies combating one type of illegal behaviour induce a substitution process towards the other kind of illegal activity or do they generate a sort of double dividend in that both types of 
unlawful activities are reduced? With the exception of fiscal corruption, the economic incentives which could provide an answer to these questions and a foundation for any kind of systematic relationship between corruption and tax evasion have not been looked at carefully yet. The present paper aims to fill part of the gap in the theoretical literature.

To analyse the relationship between corruption and corporate tax evasion, it has been assumed that production requires two complementary inputs. One input, labelled capital, can be purchased on a competitive market. The other input, labelled permits, has to be obtained from a corrupt government agency. Firms can decide on the amount of permits which they acquire legally and, thereby also on the amount of permits purchased illegally. Moreover, firms can decide on the amount of taxes which they pay. Taking the number of permits bought illegally as an indicator of corruption, it can be shown that the opportunity to evade taxes does not affect the optimal amount of corruption, for a given tax rate. However, in an economy characterised by tax evasion, the tax rate has to be higher in order to generate the same tax revenues than in an economy without tax evasion. Since higher tax rates tend to reduce corruption, this suggests a negative relationship between corruption and tax evasion. The analysis of variations in exogenous determinants of tax evasion and corruption, such as the tax deductibility of the costs of purchasing permits illegally, the level of the bribe payment or the number of permits required for production do not confirm this conjecture since any kind of relationship between the two types of criminal activities is feasible. Therefore, corruption and tax evasion are neither obvious substitutes nor clear-cut complements in the 'production' of profits. A uni-directional relationship between profit tax evasion and bureaucratic corruption can, thus, not be determined. This finding for the basic model has been confirmed by the analysis of the extensions in Section 5. In how far this result generalises to other forms of corruption and the evasion of other taxes remains an objective for future research. 


\section{References}

Alm, James (1999), Tax Compliance and Tax Administration, 741-768, in: Hildreth, W. Bartley and James A. Richardson (eds), Handbook on Taxation, New York.

Besley, Timothy and John McLaren (1993), Taxes and Bribery: The Role of Wage Incentives, The Economic Journal 103 (416), 119-141.

Bowles, Roger (1999), Tax Policy, Tax Evasion and Corruption in Economies in Transition, 67-86, in: Feige, Edgar L. and Katarina Ott (eds), Underground Economies in Transition - Unrecorded Activity, Tax Evasion, Corruption and Organized Crime, Ashgate.

Chander, Parkash and Louis Wilde (1992), Corruption in Tax Administration, Journal of Public Economics 49(3), 333-349.

Chu, C. Y. Cyrus (1990), A Model of Income Tax Evasion with Venal Tax Officials: The Case of Taiwan, Public Financel Finances Publiques 45(3), 392-408.

Dietrich, Ute and Abbo Junker (2003), Schwellenwerte in arbeitsrechtlichen Gesetzen (Threshold Levels in Labour Laws), Neue Zeitschrift für Arbeitsrecht 19, 10571068.

Friedman, Eric, Johnson, Simon, Kaufman, Daniel and Pablo Zoido-Lobaton (2000), Dodging the Grabbing Hand: the Determinants of Unofficial Activity in 69 Countries, Journal of Public Economics 76(3), 459-493.

Hindriks, Jean, Keen, Michael and Abhinay Muthoo (1999), Corruption, Extortion, and Evasion, Journal of Public Economics 74(3), 395-430.

Johnson, Simon, Kaufman, Daniel and Pablo Zoido-Lobaton (1999), Corruption, Public Finances, and the Unofficial Economy, The World Bank, WPS 2169.

Kaufmann, Daniel und Shang-Jin Wei (1999), Does "Grease Money" Speed up the Wheels of Commerce?, NBER Working Paper No. 7093.

Lee, Kangoh (1998), Tax Evasion, Monopoly, and Nonneutral Profit Taxes, National Tax Journal 51(2), 333-338.

Martinez-Vazquez, Jorge and Mark Rider (2005), Multiple Modes of Tax Evasion: Theory and Evidence, National Tax Journal 68(1), 51-76.

Panteghini, Paolo M. (2000), Tax Evasion and Entrepreneurial Flexibility, Public Finance Review 28(3), 199-209.

Sanyal, Amal (2000), Audit Hierarchy in a Corrupt Tax Administration, Journal of Comparative Economics 28(2), 364-378.

Sanyal, Amal (2002), Audit Hierarchy in a Corrupt Tax Administration: A Note with Qualifications and Extensions, Journal of Comparative Economics 30(2), 317324.

Sanyal, Amal, Gang, Ira N. and Omkar Goswami (2000), Corruption, Tax Evasion and the Laffer Curve, Public Choice 105(1-2), 61-78.

Shleifer, Andrei and Robert Vishny (1993), Corruption, Quarterly Journal of Economics 108(3), 599-617.

Tanzi, Vito and Hamid R. Davoodi (1998), Corruption, Public Investment and Growth, 41-60, in: Shibata, Hirofumi and Toshihiro Ihori (eds.), The Welfare State, Public Investment and Growth, Springer.

Tanzi, Vito and Hamid R. Davoodi (2001), Corruption, Growth, and Public Finances, 89-110, in: Arvind K. Jain (ed.), Political Economy of Corruption, Routledge.

Yaniv, Gideon (1995), A Note on the Tax Evading Firm, National Tax Journal 48(1), 113 120.

Yaniv, Gideon (1996), Tax Evasion and Monopoly Output Decisions: Note, Public Finance Quarterly 24(4), 501-505.

Yitzhaki, Shlomo (1974), A Note on Income Tax Evasion: A Theoretical Analysis, Journal of Public Economics 3(2), 201-202. 


\section{Appendix}

\subsection{Profit-maximum}

Taking into account $\pi_{\mathrm{kx}}=\mathrm{C}^{\prime \prime} \mathrm{p}^{\prime}>0, \pi_{\mathrm{xx}}=-\mathrm{C}^{\prime \prime}(1-\tau)=-\pi_{\mathrm{xk}} / \mathrm{p}^{\prime}<0, \pi_{\mathrm{kk}}=\mathrm{R}^{\prime \prime}-\mathrm{C}^{\prime \prime}\left(\mathrm{p}^{\prime}\right)^{2}-\mathrm{C}^{\prime} \mathrm{p}^{\prime \prime}<$ 0 , and $\pi_{h h}=-K^{\prime \prime} \tau(R-C-b x)<0$, the (value of the) determinant $\mathrm{D}$ of equation (3) is negative, as $\mathrm{D}=\pi_{\mathrm{kk}} \pi_{\mathrm{Xx}} \pi_{\mathrm{hh}}-\pi_{\mathrm{kx}} \pi_{\mathrm{xk}} \pi_{\mathrm{hh}}=-\pi_{\mathrm{hh}}\left[\mathrm{R}^{\prime \prime}-\mathrm{C}^{\prime} \mathrm{p}^{\prime \prime}\right] \mathrm{C}^{\prime \prime}(1-\tau)<0$. Accordingly, $0<\mathrm{h}^{*}<1, \mathrm{k}^{*}, \mathrm{x}^{*}>0$, constitute a unique after-tax profit maximum.

\subsection{Alternative Objectives (Section 5)}

If the firm's objective is given by equation $\left(1^{+}\right)$, totally differentiating the first-order conditions $\left(2 \mathrm{a}^{\prime}\right),\left(2 \mathrm{~b}^{\prime}\right)$ and $\left(2 \mathrm{c}^{+}\right)$to $\left(2 \mathrm{e}^{+}\right)$with respect to all endogenous variables $\mathrm{k}, \mathrm{x}, \mathrm{h}_{\mathrm{R}}, \mathrm{h}_{\mathrm{C}}$, $\mathrm{h}_{\mathrm{B}}$ and the exogenous variables $\alpha, \mathrm{b}, \mathrm{p}(\mathrm{k})\left(\right.$ for $\left.\mathrm{dp}^{\prime}(\mathrm{k})=0\right)$, and $\mathrm{p}^{\prime}(\mathrm{k})($ for $\mathrm{dp}(\mathrm{k})=0$ ) will yield:

$$
\begin{gathered}
{\left[\begin{array}{ccccc}
\pi_{\mathrm{kk}} & \pi_{\mathrm{kx}} & 0 & 0 & 0 \\
\pi_{\mathrm{xk}} & \pi_{\mathrm{xx}} & 0 & 0 & 0 \\
\pi_{\mathrm{h}_{\mathrm{R}}} & 0 & \pi_{\mathrm{h}_{\mathrm{R}}} \mathrm{h}_{\mathrm{R}} & 0 & 0 \\
\pi_{\mathrm{h}_{\mathrm{C}}} & \pi_{\mathrm{h}_{\mathrm{C}}} & 0 & \pi_{\mathrm{h}_{\mathrm{C}}} & 0 \\
0 & \pi_{\mathrm{h}_{\mathrm{B}}} & 0 & 0 & \pi_{\mathrm{h}_{\mathrm{B}} \mathrm{h}_{\mathrm{B}}}
\end{array}\right]\left[\begin{array}{c}
\mathrm{dk} \\
\mathrm{dx} \\
\mathrm{dh}_{\mathrm{R}} \\
\mathrm{dh}_{\mathrm{C}} \\
\mathrm{dh}_{\mathrm{B}}
\end{array}\right]} \\
=-\left[\begin{array}{cccc}
\pi_{\mathrm{k} \alpha} & 0 & \pi_{\mathrm{kp}} & \pi_{\mathrm{kp}} \\
\pi_{\mathrm{x} \alpha} & \pi_{\mathrm{xb}} & \pi_{\mathrm{xp}} & \pi_{\mathrm{xp}} \\
0 & 0 & 0 & 0 \\
0 & 0 & \pi_{\mathrm{h}_{\mathrm{Cp}}} & 0 \\
\pi_{\mathrm{h}_{\mathrm{B}} \alpha} & \pi_{\mathrm{h}_{\mathrm{B}} \mathrm{b}} & 0 & 0
\end{array}\right]\left[\begin{array}{l}
\mathrm{d} \alpha \\
\mathrm{db} \\
\mathrm{dp} \\
\mathrm{dp}
\end{array}\right]
\end{gathered}
$$

The derivatives $\pi_{\mathrm{kk}}, \pi_{\mathrm{kx}}, \pi_{\mathrm{xk}}, \pi_{\mathrm{xx}}, \pi_{\mathrm{k} \alpha}, \pi_{\mathrm{kp}}, \pi_{\mathrm{kp}}, \pi_{\mathrm{x} \alpha}, \pi_{\mathrm{xb}}, \pi_{\mathrm{xp}}, \pi_{\mathrm{xp}}$ are given in the main text or in Appendix 1. Moreover, from $\left(2 c^{+}\right)$to $\left(2 \mathrm{e}^{+}\right)$we obtain:

$$
\begin{gathered}
\pi_{\mathrm{h}_{\mathrm{R}} \mathrm{k}}=\mathrm{K}_{\mathrm{R}^{\prime \prime}} \tau \mathrm{R}^{\prime}(\mathrm{k})\left(1-\mathrm{h}_{\mathrm{R}}\right)>0 \\
\pi_{\mathrm{h}_{\mathrm{R}} \mathrm{h}_{\mathrm{R}}}=-\mathrm{K}_{\mathrm{R}}{ }^{\prime \prime} \tau \mathrm{R}(\mathrm{k})<0 \\
\pi_{\mathrm{h}_{\mathrm{C}} \mathrm{k}}=-\mathrm{K}_{\mathrm{C}^{\prime \prime}} \tau \mathrm{C}^{\prime} \mathrm{p}^{\prime}\left(\mathrm{h}_{\mathrm{C}}-1\right)=-\mathrm{p}^{\prime} \pi_{\mathrm{h}_{\mathrm{C}} \mathrm{x}}=\mathrm{p}^{\prime} \pi_{\mathrm{h}_{\mathrm{C}}}<0 \\
\pi_{\mathrm{h}_{\mathrm{C}} \mathrm{h}_{\mathrm{C}}}=-\mathrm{K}_{\mathrm{C}^{\prime \prime}} \tau \mathrm{C}(\mathrm{p}(\mathrm{k})-\mathrm{x})<0 \\
\pi_{\mathrm{h}_{\mathrm{B}}}=-\mathrm{K}_{\mathrm{B}}{ }^{\prime \prime} \tau \mathrm{b}\left(\mathrm{h}_{\mathrm{B}}-\alpha\right)=\pi_{\mathrm{h}_{\mathrm{B}}} \mathrm{b}^{\mathrm{b} / \mathrm{x}} \\
\pi_{\mathrm{h}_{\mathrm{B}} \mathrm{h}_{\mathrm{B}}}=-\mathrm{K}_{\mathrm{B}}{ }^{\prime \prime} \tau \mathrm{bx}=-\pi_{\mathrm{h}_{\mathrm{B}} \alpha}<0
\end{gathered}
$$

Applying Cramer's rule to (A.1), using (A.2) to (A.7), and simplifying yields the results for the changes in capital and corruption stated in Propositions 1 to 5 , namely that $\mathrm{dk} * / \mathrm{d} \tau, \mathrm{dx} * / \mathrm{d} \tau$ $\leq 0, \mathrm{dk}^{*} / \mathrm{db}, \mathrm{dx} * / \mathrm{db}, \mathrm{dk}^{*} / \mathrm{dp}^{\prime}<0, \mathrm{dk}^{*} / \mathrm{dp}=\mathrm{dx}^{*} / \mathrm{dp}^{\prime}=0, \mathrm{dk}^{*} / \mathrm{d} \alpha, \mathrm{dx} * / \mathrm{d} \alpha, \mathrm{dx} * / \mathrm{dp}>0$, and the findings for the evasion variables summarised in table 1 . 
If the firm's objective is given by equation $\left(1^{++}\right)$, the derivatives of the first-order conditions $\left(2 \mathrm{a}^{++}\right),\left(2 \mathrm{~b}^{++}\right)$, and $\left(2 \mathrm{c}^{++}\right)$will be given by $\pi_{\mathrm{kh}}=\pi_{\mathrm{xh}}=\pi_{\mathrm{hx}}=\pi_{\mathrm{x} \tau}=\pi_{\mathrm{kb}}=\pi_{\mathrm{xp}}=\pi_{\mathrm{hp}^{\prime}}=\pi_{\mathrm{hb}}$ $=0, \pi_{\mathrm{xb}}=-1$ and:

$$
\begin{aligned}
\pi_{\mathrm{kk}}=\mathrm{R}^{\prime \prime}(\mathrm{k})(1-\tau)-\left(\mathrm{p}^{\prime}(\mathrm{k})\right)^{2}\left[\mathrm{C}^{\prime \prime}(\mathrm{p}(\mathrm{k})-\mathrm{x})-\tau \mathrm{C}^{\prime \prime}(\mathrm{p}(\mathrm{k}))\right]-\mathrm{p}^{\prime \prime}(\mathrm{k})\left[\mathrm{C}^{\prime}(\mathrm{p}(\mathrm{k})-\mathrm{x})-\tau \mathrm{C}^{\prime}(\mathrm{p}(\mathrm{k}))\right] \\
\pi_{\mathrm{kx}}=\pi_{\mathrm{xk}}=\mathrm{C}^{\prime \prime}(\mathrm{p}(\mathrm{k})-\mathrm{x}) \mathrm{p}^{\prime}(\mathrm{k})>0 \\
\pi_{\mathrm{xx}}=-\mathrm{C}^{\prime \prime}(\mathrm{p}(\mathrm{k})-\mathrm{x})=-\pi_{\mathrm{xp}}<0 \\
\pi_{\mathrm{hh}}=-\mathrm{K}^{\prime \prime} \tau(\mathrm{R}(\mathrm{k})-\mathrm{C}(\mathrm{p}(\mathrm{k})))<0 \\
\pi_{\mathrm{hk}}=\mathrm{K}^{\prime \prime} \tau\left(\mathrm{R}^{\prime}(\mathrm{k})-\mathrm{C}^{\prime}(\mathrm{p}(\mathrm{k})) \mathrm{p}^{\prime}(\mathrm{k})\right)(1-\mathrm{h})>0 \\
\pi_{\mathrm{k} \tau}=-\left(\mathrm{R}^{\prime}(\mathrm{k})-\mathrm{C}^{\prime}(\mathrm{p}(\mathrm{k})) \mathrm{p}^{\prime}(\mathrm{k})\right)<0 \\
\pi_{\mathrm{h} \tau}=\mathrm{K}^{\prime \prime}(\mathrm{R}(\mathrm{k})-\mathrm{C}(\mathrm{p}(\mathrm{k})))>0 \\
\pi_{\mathrm{kp}}=-\mathrm{C}^{\prime \prime}(\mathrm{p}(\mathrm{k})-\mathrm{x}) \mathrm{p}^{\prime}(\mathrm{k})+\tau \mathrm{C}^{\prime \prime}(\mathrm{p}(\mathrm{k})) \mathrm{p}^{\prime}(\mathrm{k}) \\
\pi_{\mathrm{hp}}=-\mathrm{K}^{\prime \prime} \tau \mathrm{C}^{\prime}(\mathrm{p}(\mathrm{k}))(1-\mathrm{h})<0 \\
\pi_{\mathrm{kp}{ }^{\prime}}=-\mathrm{C}^{\prime}(\mathrm{p}(\mathrm{k})-\mathrm{x})+\tau \mathrm{C}^{\prime}(\mathrm{p}(\mathrm{k}))<0
\end{aligned}
$$

Note from $\left(2 \mathrm{a}^{++}\right)$that an interior solution implies $\mathrm{R}^{\prime}(\mathrm{k})-\mathrm{C}^{\prime}(\mathrm{p}(\mathrm{k})-\mathrm{x}) \mathrm{p}^{\prime}(\mathrm{k})>0, \mathrm{R}^{\prime}(\mathrm{k})-$ $\mathrm{C}^{\prime}(\mathrm{p}(\mathrm{k})) \mathrm{p}^{\prime}(\mathrm{k})>0$, and $\mathrm{C}^{\prime}(\mathrm{p}(\mathrm{k})-\mathrm{x})-\tau \mathrm{C}(\mathrm{p}(\mathrm{k}))>0$, allowing to sign (A.12), (A.13) and (A.17). Employing the same methodology as it has been used in the computations for the basic model of Section 2 yields $\mathrm{dk}^{*} / \mathrm{d} \tau, \mathrm{dk} * / \mathrm{db}, \mathrm{dk}^{*} / \mathrm{dp}^{\prime}, \mathrm{dx} * / \mathrm{d} \tau, \mathrm{dx} * / \mathrm{db}, \mathrm{dx} * / \mathrm{dp}^{\prime}, \mathrm{dh}^{*} / \mathrm{db}<0, \mathrm{dk}^{*} / \mathrm{dp}$, $\mathrm{dh} * / \mathrm{dp}^{\prime}>0$, and $\mathrm{dx} * / \mathrm{dp}>1$, while $\mathrm{dh} * / \mathrm{dp}$ cannot be signed. 


\section{CESifo Working Paper Series}

(for full list see www.cesifo-group.de)

1605 Kathleen M. Day and Stanley L. Winer, Policy-induced Internal Migration: An Empirical Investigation of the Canadian Case, November 2005

1606 Paul De Grauwe and Cláudia Costa Storti, Is Monetary Policy in the Eurozone less Effective than in the US?, November 2005

1607 Per Engström and Bertil Holmlund, Worker Absenteeism in Search Equilibrium, November 2005

1608 Daniele Checchi and Cecilia García-Peñalosa, Labour Market Institutions and the Personal Distribution of Income in the OECD, November 2005

1609 Kai A. Konrad and Wolfgang Leininger, The Generalized Stackelberg Equilibrium of the All-Pay Auction with Complete Information, November 2005

1610 Monika Buetler and Federica Teppa, Should you Take a Lump-Sum or Annuitize? Results from Swiss Pension Funds, November 2005

1611 Alexander W. Cappelen, Astri D. Hole, Erik Ø. Sørensen and Bertil Tungodden, The Pluralism of Fairness Ideals: An Experimental Approach, December 2005

1612 Jack Mintz and Alfons J. Weichenrieder, Taxation and the Financial Structure of German Outbound FDI, December 2005

1613 Rosanne Altshuler and Harry Grubert, The Three Parties in the Race to the Bottom: Host Governments, Home Governments and Multinational Companies, December 2005

1614 Chi-Yung (Eric) Ng and John Whalley, Visas and Work Permits: Possible Global Negotiating Initiatives, December 2005

1615 Jon H. Fiva, New Evidence on Fiscal Decentralization and the Size of Government, December 2005

1616 Andzelika Lorentowicz, Dalia Marin and Alexander Raubold, Is Human Capital Losing from Outsourcing? Evidence for Austria and Poland, December 2005

1617 Aleksander Berentsen, Gabriele Camera and Christopher Waller, Money, Credit and Banking, December 2005

1618 Egil Matsen, Tommy Sveen and Ragnar Torvik, Savers, Spenders and Fiscal Policy in a Small Open Economy, December 2005

1619 Laszlo Goerke and Markus Pannenberg, Severance Pay and the Shadow of the Law: Evidence for West Germany, December 2005 
1620 Michael Hoel, Concerns for Equity and the Optimal Co-Payments for Publicly Provided Health Care, December 2005

1621 Edward Castronova, On the Research Value of Large Games: Natural Experiments in Norrath and Camelot, December 2005

1622 Annette Alstadsæter, Ann-Sofie Kolm and Birthe Larsen, Tax Effects, Search Unemployment, and the Choice of Educational Type, December 2005

1623 Vesa Kanniainen, Seppo Kari and Jouko Ylä-Liedenpohja, Nordic Dual Income Taxation of Entrepreneurs, December 2005

1624 Lars-Erik Borge and Linn Renée Naper, Efficiency Potential and Efficiency Variation in Norwegian Lower Secondary Schools, December 2005

1625 Sam Bucovetsky and Andreas Haufler, Tax Competition when Firms Choose their Organizational Form: Should Tax Loopholes for Multinationals be Closed?, December 2005

1626 Silke Uebelmesser, To go or not to go: Emigration from Germany, December 2005

1627 Geir Haakon Bjertnæs, Income Taxation, Tuition Subsidies, and Choice of Occupation: Implications for Production Efficiency, December 2005

1628 Justina A. V. Fischer, Do Institutions of Direct Democracy Tame the Leviathan? Swiss Evidence on the Structure of Expenditure for Public Education, December 2005

1629 Torberg Falch and Bjarne Strøm, Wage Bargaining and Political Strength in the Public Sector, December 2005

1630 Hartmut Egger, Peter Egger, Josef Falkinger and Volker Grossmann, International Capital Market Integration, Educational Choice and Economic Growth, December 2005

1631 Alexander Haupt, The Evolution of Public Spending on Higher Education in a Democracy, December 2005

1632 Alessandro Cigno, The Political Economy of Intergenerational Cooperation, December 2005

1633 Michiel Evers, Ruud A. de Mooij and Daniel J. van Vuuren, What Explains the Variation in Estimates of Labour Supply Elasticities?, December 2005

1634 Matthias Wrede, Health Values, Preference Inconsistency, and Insurance Demand, December 2005

1635 Hans Jarle Kind, Marko Koethenbuerger and Guttorm Schjelderup, Do Consumers Buy Less of a Taxed Good?, December 2005

1636 Michael McBride and Stergios Skaperdas, Explaining Conflict in Low-Income Countries: Incomplete Contracting in the Shadow of the Future, December 2005 
1637 Alfons J. Weichenrieder and Oliver Busch, Artificial Time Inconsistency as a Remedy for the Race to the Bottom, December 2005

1638 Aleksander Berentsen and Christopher Waller, Optimal Stabilization Policy with Flexible Prices, December 2005

1639 Panu Poutvaara and Mikael Priks, Violent Groups and Police Tactics: Should Tear Gas Make Crime Preventers Cry?, December 2005

1640 Yin-Wong Cheung and Kon S. Lai, A Reappraisal of the Border Effect on Relative Price Volatility, January 2006

1641 Stefan Bach, Giacomo Corneo and Viktor Steiner, Top Incomes and Top Taxes in Germany, January 2006

1642 Johann K. Brunner and Susanne Pech, Optimum Taxation of Life Annuities, January 2006

1643 Naércio Aquino Menezes Filho, Marc-Andreas Muendler and Garey Ramey, The Structure of Worker Compensation in Brazil, with a Comparison to France and the United States, January 2006

1644 Konstantinos Angelopoulos, Apostolis Philippopoulos and Vanghelis Vassilatos, RentSeeking Competition from State Coffers: A Calibrated DSGE Model of the Euro Area, January 2006

1645 Burkhard Heer and Bernd Suessmuth, The Savings-Inflation Puzzle, January 2006

1646 J. Stephen Ferris, Soo-Bin Park and Stanley L. Winer, Political Competition and Convergence to Fundamentals: With Application to the Political Business Cycle and the Size of Government, January 2006

1647 Yu-Fu Chen, Michael Funke and Kadri Männasoo, Extracting Leading Indicators of Bank Fragility from Market Prices - Estonia Focus, January 2006

1648 Panu Poutvaara, On Human Capital Formation with Exit Options: Comment and New Results, January 2006

1649 Anders Forslund, Nils Gottfries and Andreas Westermark, Real and Nominal Wage Adjustment in Open Economies, January 2006

1650 M. Hashem Pesaran, Davide Pettenuzzo and Allan G. Timmermann, Learning, Structural Instability and Present Value Calculations, January 2006

1651 Markku Lanne and Helmut Luetkepohl, Structural Vector Autoregressions with Nonnormal Residuals, January 2006

1652 Helge Berger, Jakob de Haan and Jan-Egbert Sturm, Does Money Matter in the ECB Strategy? New Evidence Based on ECB Communication, January 2006 
1653 Axel Dreher and Friedrich Schneider, Corruption and the Shadow Economy: An Empirical Analysis, January 2006

1654 Stefan Brandauer and Florian Englmaier, A Model of Strategic Delegation in Contests between Groups, January 2006

1655 Jan Zápal and Ondřej Schneider, What are their Words Worth? Political Plans and Economic Pains of Fiscal Consolidations in New EU Member States, January 2006

1656 Thiess Buettner, Sebastian Hauptmeier and Robert Schwager, Efficient Revenue Sharing and Upper Level Governments: Theory and Application to Germany, January 2006

1657 Daniel Haile, Abdolkarim Sadrieh and Harrie A. A. Verbon, Cross-Racial Envy and Underinvestment in South Africa, February 2006

1658 Frode Meland and Odd Rune Straume, Outsourcing in Contests, February 2006

1659 M. Hashem Pesaran and Ron Smith, Macroeconometric Modelling with a Global Perspective, February 2006

1660 Alexander F. Wagner and Friedrich Schneider, Satisfaction with Democracy and the Environment in Western Europe - a Panel Analysis, February 2006

1661 Ben J. Heijdra and Jenny E. Ligthart, Fiscal Policy, Monopolistic Competition, and Finite Lives, February 2006

1662 Ludger Woessmann, Public-Private Partnership and Schooling Outcomes across Countries, February 2006

1663 Topi Miettinen and Panu Poutvaara, Political Parties and Network Formation, February 2006

1664 Alessandro Cigno and Annalisa Luporini, Optimal Policy Towards Families with Different Amounts of Social Capital, in the Presence of Asymmetric Information and Stochastic Fertility, February 2006

1665 Samuel Muehlemann and Stefan C. Wolter, Regional Effects on Employer Provided Training: Evidence from Apprenticeship Training in Switzerland, February 2006

1666 Laszlo Goerke, Bureaucratic Corruption and Profit Tax Evasion, February 2006 